\title{
Temporomandibular Joint Disorders and its Relationship with Parafunctional Habits among Undergraduate Medical and Dental Students
}

\author{
Sudeep Acharya, ${ }^{1}$ Rajib Chaulagain, ${ }^{2}$ Amita Pradhan, ${ }^{3}$ Ankur Shah ${ }^{4}$ \\ ${ }^{1}$ Department of Oral and Maxillofacial Surgery, ${ }^{2}$ Department of Oral Pathology, ${ }^{3}$ Department of Community Medicine, \\ ${ }^{3}$ Deparment of Radiology, KIST Medical College and Teaching Hospital, Imadol, Lalitpur, Nepal.
}

\begin{abstract}
Background: Temporomandibular disorder is a term used to describe problems involving temporomandibular joint, muscles of mastication, occlusion characterized by symptoms such as pain, restricted movements and intermittent joint sound. The present study was conducted to determine prevalence of TMD and to describe its association with parafunctional habits. Materials and Methods: A cross-sectional study was carried out among 345 undergraduate students of KIST Medical College and Hospital. Study population was selected by simple random sampling and the Fonseca Anamnestic Questionnaires were distributed. Data analysis was done in SPSS version 16 . Results: The prevalence of TMD was $47.4 \%$ with mild and moderate type of TMD present. The most common habit was chewing gums followed by biting of lips and biting of objects. Statistically significant difference in TMD groups was observed in clenching and grinding of teeth, biting of lips and biting of objects $(p<0.001)$. There was statistically significant association between TMD and the signs and symptoms such as headaches, difficult to open mouth, muscular pain while chewing $(\mathrm{p}<0.001)$. Conclusions: A statistically significant association was found between biting of lips, grinding of teeth and mouth breathing with TMD.
\end{abstract}

Keywords: parafunctional habits; prevalence; TMD .

\section{INTRODUCTION}

The temporomandibular joint disorder (TMD) has been subject of study from a long time. TMD is a collective term encompassing several clinical problems involving masticatory musculature and the temporomandibular joint (TMJ). It is characterized by pain the temporomandibular joint region, fatigue of the muscles of mastication, limitations in jaw movements and production of sounds in the temporomandibular joint. ${ }^{1}$ The etiology of TMD is multifactorial and has been attributed to emotional tension, occlusal interferences, loss of teeth, dysfunction of muscles of mastication and internal and external changes in the TMJ structure. ${ }^{2}$ TMDs are the most common orofacial pain conditions of non-dental origin and are self-limited to adult populations. The prevalence rates of TMDs also vary between studies reflecting differences in sampling criteria and methodology used for collecting information. ${ }^{3}$

The diagnosis of TMD is a complex process as different anatomic structures are involved. A number of assessment tools have been developed for use in clinical practice and for epidemiological studies. $^{4}$ The severity of TMD has been widely analysed in clinical and epidemiological studies using Fonseca's anamnestic index. Fonseca classified TMD signs and symptoms as mild, moderate and severe or non-TMD. This index was developed based upon Helkimo index. The anamnestic and clinical index proposed by Helkimo was used to determine the severity of subjective symptoms. $^{5}$

Studies have shown the association of oral habits such as lip biting, nail biting with TMDs among adolescent. ${ }^{6,7}$ Motghare et al., ${ }^{7}$ have also shown the association between nail biting, lip biting and grinding of teeth with signs and symptoms of TMD. However, study pertaining to prevalence of TMD and/or in association with parafunctional habits has not been conducted in Nepal till date. The aim of the present study was to evaluate the prevalence of TMD and its association with parafunctional habits among the medical and dental undergraduates at KIST medical college and hospital.

Correspondence: Dr. Sudeep Acharya, Department of Oral and Maxillofacial Surgery, KIST Medical College and Teaching Hospital, Imadol, Lalitpur, Nepal. Email: drsudeepacharya@gmail.com. Phone: +9779851147241. DOI: dx.doi.org/10.3126/jcmsn.v14i3.20289. Orcid ID: orcid.org/0000-0002-2805-6554. Article received: 2018-06-15. Article accepted: 2018-09-10. 


\section{MATERIALS AND METHODS}

The study was cross-sectional type, carried out from March 2018 to May 2018, consisting participants from both genders. To estimate the prevalence of temporomandibular disorder, we assumed prevalence $(\mathrm{p})=22.4 \%$ as suggested by Agarwal et al., ${ }^{8}$ at $95 \%$ confidence level and maximum tolerable error of $20 \%$ of prevalence (p), the minimum sample size calculated was 330 .

A list of all the students (total 548) was obtained from the student section of the KIST Medical College. Then all the students were assigned with an arbitrary number. Computer generated random numbers was used for selection of sample. To avoid non-response the sample was taken as 345 .

Before starting the study ethical approval was obtained from the Institutional Review Committee at KIST medical college and hospital (IRC no: 2074/75/15). All the participants were informed on the aims and objectives of the study and they signed formal informed consent prior to participation. The participants were instructed on how to fill out the questionnaire. The questionnaires were to be answered individually and with no time constraints. Inclusion criteria for the study were: Students with all permanent dentition and those participants who had to give response of yes, no and sometimes. Each answer was given a value, score ' 0 ' for ' $N o$ ', score ' 5 ' for 'sometimes' and score '10' for 'Yes' response. The sum of the scores was used to group the participants into four categories. ${ }^{8}$

Score 0-15: - No dysfunction

Score 20-45: - Mild TMD

Score 50-65: - Moderate TMD

Score 70-100: - Severe TMD

The collected data was entered in Microsoft Excel and then transferred to SPSS version 16. After proper cleaning of the data, it was analysed by using descriptive statistics. Pearson's Chi-Square test was used to observe the association between TMD, parafunctional habits. In addition, Kruskal Wallis Chi-square test was also used. Multivariate logistic regression analysis was used to study the influence of different variables with TMD.

\section{RESULTS}

The study population comprised of 133 (38.6\%) male and $212(61.4 \%)$ females with mean age (in years) $20.66 \pm 1.72$. A total of $41.2 \%$ had mild TMD, $5.2 \%$ had moderate TMD and none of the participants had severe TMD while more than half $(53.6 \%)$ did not have TMD. No statistically significant difference was found among TMD groups between males and females (Table 1).

Table 1. Distribution of students according to sex and different grades of temporomandibular disorders.

\begin{tabular}{|l|l|l|l|l|l|l|}
\hline \multirow{2}{*}{} & \multicolumn{3}{|c|}{ TMD Group } & Total & $\begin{array}{c}\text { Pearson's } \\
\text { Chi-Square } \\
\text { test }\end{array}$ & $\begin{array}{c}\text { p- } \\
\text { value }\end{array}$ \\
\cline { 2 - 5 } & $\begin{array}{l}\text { No Dysfunction } \\
185(53.6 \%)\end{array}$ & $\begin{array}{l}\text { Mild } \\
142(41.2 \%)\end{array}$ & $\begin{array}{l}\text { Moderate } \\
18(5.2 \%)\end{array}$ & $345(100 \%)$ & 2.371 & 0.306 \\
\hline Male & $78(58.6 \%)$ & $48(36.1 \%)$ & $7(5.3 \%)$ & $133(100 \%)$ & & \\
\hline Female & $107(50.5 \%)$ & $94(44.3 \%)$ & $11(5.2 \%)$ & $212(100 \%)$ & & \\
\hline
\end{tabular}

were not undergoing orthodontic treatment.

Exclusion criteria for the study were students with clinical diagnosis of TMD and undergoing or undergone treatment and medication, students who had history of trauma to the face and TMJ and had surgical intervention on their face in past six months and students with gross pathology of ear.

The study consists of three parts. The first part consisted of demographic characteristics of the subject such as age, sex, programme of study, year and address. The second part consisted of list of parafunctional habits in which the answer was 'Yes' or 'No'. The third part contained Fonseca Anamnestic Questionnaires used to assess the severity of signs and symptoms of TMD. The index consists of ten questions in which the participants
The most common habits were chewing gums $(48.1 \%)$, biting of lips $(33 \%)$, biting of objects (26.4) while nail biting and mouth breathing were also present in $20 \%$ of participants (Table 2).

\begin{tabular}{|c|c|c|}
\hline $\begin{array}{l}\text { Parafunctional } \\
\text { habits }(n=\mathbf{3 4 5})\end{array}$ & $\begin{array}{c}\text { Yes } \\
\text { Frequency } \\
\text { (Percent) }\end{array}$ & $\begin{array}{c}\text { No } \\
\text { Frequency } \\
\text { (Percent) }\end{array}$ \\
\hline Nail Biting & $69(20 \%)$ & $276(80 \%)$ \\
\hline Clenching & $44(12.8 \%)$ & $301(87.2)$ \\
\hline Grinding & $24(7 \%)$ & $321(93 \%)$ \\
\hline Biting of Lips & $114(33 \%)$ & $231(67 \%)$ \\
\hline Biting of Objects & $91(26.4 \%)$ & $254(73.6 \%)$ \\
\hline Chewing Gums & $166(48.1 \%)$ & $179(51.9 \%)$ \\
\hline Finger sucking & $9(2.6 \%)$ & $336897.4 \%)$ \\
\hline Mouth Breathing & $69(20 \%)$ & $276(80 \%)$ \\
\hline
\end{tabular}

Statistically significant difference in TMD groups 
Acharya et al. Temporomandibular Joint Disorders and its Relationship with parafunctional..

was not observed in nail biting, chewing gums and finger sucking (Table 3).
(S.E.) were less than 2, we assumed that multicollinearity between independent variables

\begin{tabular}{|c|c|c|c|c|c|c|c|}
\hline \multirow[b]{2}{*}{$\begin{array}{c}\text { Parafunctional } \\
\text { Habits }\end{array}$} & & \multicolumn{3}{|c|}{ TMDgroup } & \multirow{2}{*}{\multicolumn{2}{|c|}{$\begin{array}{l}\text { Pearson's } \\
\text { Chi-Square }\end{array}$}} & \multirow{2}{*}{ p-value } \\
\hline & & Nodycfunction & Mild & Modorets & & & \\
\hline \multirow[t]{2}{*}{ Nail Biting } & Yes & 34 (18.4\%) & $29(20.4 \%)$ & $6(33.3 \%)$ & 69 & \multirow{2}{*}{2.32} & \multirow{2}{*}{0.314} \\
\hline & No & $151(81.6 \%)$ & $113(79.6 \%)$ & $12(66.7 \%)$ & 276 & & \\
\hline \multirow[t]{2}{*}{ Clenching } & Yes & $12(6.5 \%)$ & $23(16.2 \%)$ & $9(50.0 \%)$ & 44 & \multirow[t]{2}{*}{30.485} & \multirow[t]{2}{*}{$<0.001$} \\
\hline & No & $173(93.5 \%)$ & $119(83.8 \%)$ & $9(50.0 \%)$ & 301 & & \\
\hline \multirow[t]{2}{*}{ Grinding } & Yes & $4(2.2 \%)$ & $15(10.6 \%)$ & $5(27.8 \%)$ & 24 & \multirow[t]{2}{*}{21.48} & \multirow[t]{2}{*}{$<0.001$} \\
\hline & No & $181(97.8 \%)$ & $127(89.4 \%)$ & $13(72.2 \%)$ & 321 & & \\
\hline \multirow[t]{2}{*}{ Biting of Lips } & Yes & $38(20.5 \%)$ & $64(45.1 \%)$ & $12(66.7 \%)$ & 114 & \multirow[t]{2}{*}{31.552} & \multirow[t]{2}{*}{$<0.001$} \\
\hline & No & $147(79.5 \%)$ & $78(54.9 \%)$ & $6(33.3 \%)$ & 231 & & \\
\hline \multirow[t]{2}{*}{ Biting of Objects } & Yes & $37(20.0 \%)$ & $44(31.0 \%)$ & $10(55.6 \%)$ & 91 & \multirow[t]{2}{*}{13.319} & \multirow[t]{2}{*}{$<0.001$} \\
\hline & No & $148(80.0 \%)$ & $98(69.0 \%)$ & $8(44.4 \%)$ & 254 & & \\
\hline \multirow[t]{2}{*}{ Chewing Gums } & Yes & $81(43.8 \%)$ & $74(52.1 \%)$ & $11(61.1 \%)$ & 166 & \multirow[t]{2}{*}{3.517} & \multirow[t]{2}{*}{0.172} \\
\hline & No & $104(56.2 \%)$ & $68(47.9 \%)$ & $7(38.9 \%)$ & 179 & & \\
\hline \multirow[t]{2}{*}{ Finger sucking } & Yes & $2(1.1 \%)$ & & $7(4.4 \%)^{*}$ & 9 & \multirow[t]{2}{*}{6.43} & \multirow[t]{2}{*}{0.039} \\
\hline & No & $183(98.9 \%)$ & & $153(95.6 \%)^{*}$ & 336 & & \\
\hline \multirow[t]{2}{*}{ Mouth Breathing } & Yes & $25(13.5 \%)$ & $34(23.9 \%)$ & $10(55.6 \%)$ & 69 & \multirow[t]{2}{*}{20.467} & \multirow[t]{2}{*}{$<0.001$} \\
\hline & No & $160(86.5 \%)$ & $108(76.1 \%)$ & $8(44.4 \%)$ & 276 & & \\
\hline
\end{tabular}

*Chi-square test with continuity correction done, as Chi-square test can't be performed mild to moderate TMD has been merged.

Feeling of a tense person was the most frequent sign of TMD $(56 \%, n=193)$. Headache was the second frequent sign which was reported by 168 participants $(48.7 \%)$. A total of $119(31.6 \%)$ reported tiredness or muscular pain while chewing (Table 4). does not exist. At the same time, the multicollinearity was assessed by VIF calculated using linear regression. None of the variables had VIF greater than 10 suggesting no multicollinearity. A statistically significant association was found between grinding to teeth, biting of lips and mouth

\begin{tabular}{|c|c|c|c|}
\hline Fonseca Anamnestic Questionnaire & No & Sometimes & Yes \\
\hline Is it hard for you to open your mouth? & $323(93.6 \%)$ & $18(5.2 \%)$ & $4(1.2 \%)$ \\
\hline Is it hard for you to move your mandible from side to side? & $335(97.1 \%)$ & $7(2 \%)$ & $3(0.9 \%)$ \\
\hline Do you get tired /muscular pain while chewing? & $236(68.4 \%)$ & $73(21.2 \%)$ & $36(10.4 \%)$ \\
\hline Do you have frequent headaches? & $177(51.3 \%)$ & $81(23.5 \%)$ & $87(25.2 \%)$ \\
\hline Do you have pain on the nape or stiff neck? & $259(75.1 \%)$ & $54(15.7 \%)$ & $32(9.3 \%)$ \\
\hline Do you have earaches or pain in craniomandibular joints? & $309(89.6 \%)$ & $27(7.8 \%)$ & $9(2.6 \%)$ \\
\hline $\begin{array}{l}\text { Have you noticed any TMJ clicking while chewing or when you } \\
\text { open your mouth? }\end{array}$ & $253(73,3 \%)$ & $48(13.9 \%)$ & $44(12.8 \%)$ \\
\hline Do you clench or grind your teeth? & $283(82 \%)$ & $36(10.4 \%)$ & $26(7.5 \%)$ \\
\hline Do you feel your teeth do not articulate well? & $280(81.2 \%)$ & $17(4.9 \%)$ & $48(13.9 \%)$ \\
\hline Do you consider yourself a tense (nervous) person? & $152(44.1 \%)$ & $100(29 \%)$ & $93(27 \%)$ \\
\hline
\end{tabular}

There was statistically significant association between TMD and the signs and symptoms such as headaches, difficult to open mouth, muscular pain while chewing $(\mathrm{p}<0.001)$ (Table 5). A multivariate logistic regression analysis was shown in Table 6 . Dependent variable was TMD score which was categorized as no TMD and mild to moderate TMD. Those variables which were not significant $(p>0.05)$, were excluded from multivariate logistic regression analysis. As all the standard errors breathing $(\mathrm{p}<0.05)$. Results showed that people who grind were 3.4 times more likely to develop TMD than the one who do not grind at all. People who bite their lips were 2.7 times more likely to develop TMD. Similarly, mouth breathers were 1.9 times more likely to develop TMD (Table 6). Hosmer and Lemeshow test showed that the model described in Table 6 adequately fits the data (chi square $=2.21$, $\mathrm{p}=0.82$ ). 
Acharya et al. Temporomandibular Joint Disorders and its Relationship with parafunctional..

\begin{tabular}{|c|c|c|c|c|c|c|c|}
\hline $\begin{array}{c}\text { Fonseca Anamnestic Ques- } \\
\text { tionnaire }\end{array}$ & & $\begin{array}{l}\text { no dysfunc- } \\
\text { tion }\end{array}$ & $\begin{array}{c}\text { TMD group } \\
\text { mild }\end{array}$ & moderate & Total & $\begin{array}{c}\text { Kruskal- } \\
\text { Wallis chi- } \\
\text { square test }\end{array}$ & p-value \\
\hline $\begin{array}{l}\text { Is it hard for you to open your } \\
\text { mouth? }\end{array}$ & $\begin{array}{l}\text { No } \\
\text { Sometimes } \\
\text { Yes } \\
\text { Median }(\mathrm{Q} 1, \mathrm{Q} 3)\end{array}$ & $\begin{array}{r}184(99.5 \%) \\
1(0.5 \%) \\
0 \\
0(0,0)\end{array}$ & $\begin{array}{r}126(88.7 \%) \\
15(10.6 \%) \\
1(0.7 \%) \\
0(0,0)\end{array}$ & $\begin{array}{r}13(72.2 \%) \\
2(11.1 \%) \\
3(16.7 \%) \\
0(0,5)\end{array}$ & $\begin{array}{r}323 \\
18 \\
4\end{array}$ & 18.71 & $<0.001$ \\
\hline $\begin{array}{l}\text { Is it hard for you to move } \\
\text { your mandible from side to } \\
\text { side? }\end{array}$ & $\begin{array}{l}\text { No } \\
\text { Sometimes } \\
\text { Yes } \\
\text { Median }(\mathrm{Q} 1, \mathrm{Q} 3)\end{array}$ & $\begin{array}{r}185(100 \%) \\
0 \\
0 \\
0(0,0)\end{array}$ & $\begin{array}{r}135(95.1 \%) \\
6(4.2 \%) \\
1(0.7 \%) \\
0(0,0)\end{array}$ & $\begin{array}{r}15(83.3 \%) \\
1(5.6 \%) \\
2(11.1 \%) \\
0(0,0)\end{array}$ & $\begin{array}{r}335 \\
7 \\
3\end{array}$ & 9.29 & 0.002 \\
\hline $\begin{array}{l}\text { Do you get tired /muscular } \\
\text { pain while chewing? }\end{array}$ & $\begin{array}{l}\text { No } \\
\text { Sometimes } \\
\text { Yes } \\
\text { Median }(\mathrm{Q} 1, \mathrm{Q} 3)\end{array}$ & $\begin{array}{r}161(87.0 \%) \\
22(11.9 \%) \\
2(1.1 \%) \\
0(0,0)\end{array}$ & $\begin{array}{r}71(50.0 \%) \\
48(33.8 \%) \\
23(16.2 \%) \\
2.5(0,5)\end{array}$ & $\begin{array}{r}4(22.2 \%) \\
3(16.7 \%) \\
11(61.1 \%) \\
10(3.75,10)\end{array}$ & $\begin{array}{r}236 \\
73 \\
36\end{array}$ & 56.55 & $<0.001$ \\
\hline $\begin{array}{c}\text { Do you have frequent head- } \\
\text { aches? }\end{array}$ & $\begin{array}{l}\text { No } \\
\text { Sometimes } \\
\text { Yes } \\
\text { Median }(\mathrm{Q} 1, \mathrm{Q} 3)\end{array}$ & $\begin{array}{r}130(70.3 \%) \\
40(21.6 \%) \\
15(8.1 \%) \\
0(0,5)\end{array}$ & $\begin{array}{r}46(32.4 \%) \\
39(27.5 \%) \\
57(40.1 \%) \\
5(0,10)\end{array}$ & $\begin{array}{r}1(5.6 \%) \\
2(11.1 \%) \\
15(83.3 \%) \\
10(10,10)\end{array}$ & $\begin{array}{r}177 \\
81 \\
87\end{array}$ & 57.63 & $<0.001$ \\
\hline $\begin{array}{c}\text { Do you have pain on the nape } \\
\text { or stiff neck? }\end{array}$ & $\begin{array}{l}\text { No } \\
\text { Sometimes } \\
\text { Yes } \\
\text { Median }(\mathrm{Q} 1, \mathrm{Q} 3)\end{array}$ & $\begin{array}{r}166(89.7 \%) \\
15(8.1 \%) \\
4(2.2 \%) \\
0(0,0)\end{array}$ & $\begin{array}{r}85(59.9 \%) \\
36(25.4 \%) \\
21(14.8 \%) \\
0(0,5)\end{array}$ & $\begin{array}{r}8(44.4 \%) \\
3(16.7 \%) \\
7(38.9 \%) \\
5(0,10)\end{array}$ & $\begin{array}{r}259 \\
54 \\
32\end{array}$ & 41.18 & $<0.001$ \\
\hline $\begin{array}{l}\text { Do you have earaches or pain } \\
\text { in craniomandibular joints? }\end{array}$ & $\begin{array}{l}\text { No } \\
\text { Sometimes } \\
\text { Yes } \\
\text { Median }(\mathrm{Q} 1, \mathrm{Q} 3)\end{array}$ & $\begin{array}{r}181(97.8 \%) \\
4(2.2 \%) \\
0 \\
0(0,0)\end{array}$ & $\begin{array}{r}116(81.7 \%) \\
20(14.1 \%) \\
6(4.2 \%) \\
0(0,0)\end{array}$ & $\begin{array}{r}12(66.7 \%) \\
3(16.7 \%) \\
3(16.7 \%) \\
0(0,5)\end{array}$ & $\begin{array}{r}309 \\
27 \\
9\end{array}$ & 25.31 & $<0.001$ \\
\hline $\begin{array}{l}\text { Have you noticed any TMJ } \\
\text { clicking while chewing or } \\
\text { when you open your mouth? }\end{array}$ & $\begin{array}{l}\text { No } \\
\text { Sometimes } \\
\text { Yes } \\
\text { Median }(Q 1, Q 3)\end{array}$ & $\begin{array}{r}167(90.3 \%) \\
13(7.0 \%) \\
5(2.7 \%) \\
0(0,0)\end{array}$ & $\begin{array}{r}81(57.0 \%) \\
32(22.5 \%) \\
29(20.4 \%) \\
0(0,5)\end{array}$ & $\begin{array}{r}5(27.8 \%) \\
3(16.7 \%) \\
10(55.6 \%) \\
10(0,10)\end{array}$ & $\begin{array}{r}253 \\
48 \\
44\end{array}$ & 49.75 & $<0.001$ \\
\hline $\begin{array}{l}\text { Do you clench or grind your } \\
\text { teeth? }\end{array}$ & $\begin{array}{l}\text { No } \\
\text { Sometimes } \\
\text { Yes } \\
\text { Median }(Q 1, Q 3)\end{array}$ & $\begin{array}{r}173(93.5 \%) \\
9(4.9 \%) \\
3(1.6 \%) \\
0(0,0)\end{array}$ & $\begin{array}{r}103(72.5 \%) \\
26(18.3 \%) \\
13(9.2 \%) \\
0(0,5)\end{array}$ & $\begin{array}{r}7(38.9 \%) \\
1(5.6 \%) \\
10(55.6 \%) \\
10(0,10)\end{array}$ & $\begin{array}{r}283 \\
36 \\
26\end{array}$ & 26.99 & $<0.001$ \\
\hline $\begin{array}{c}\text { Do you feel your teeth do not } \\
\text { articulate well? }\end{array}$ & $\begin{array}{l}\text { No } \\
\text { Sometimes } \\
\text { Yes } \\
\text { Median }(Q 1, Q 3)\end{array}$ & $\begin{array}{r}169(91.4 \%) \\
9(4.9 \%) \\
7(3.8 \%) \\
0(0,0)\end{array}$ & $\begin{array}{r}107(75.4 \%) \\
6(4.2 \%) \\
29(20.4 \%) \\
0(0,1.25)\end{array}$ & $\begin{array}{r}4(22.2 \%) \\
2(11.1 \%) \\
12(66.7 \%) \\
10(3.75,10)\end{array}$ & $\begin{array}{r}280 \\
17 \\
48\end{array}$ & 17.14 & $<0.001$ \\
\hline $\begin{array}{l}\text { Do you consider yourself a } \\
\text { tense (nervous) person? }\end{array}$ & $\begin{array}{l}\text { No } \\
\text { Sometimes } \\
\text { Yes } \\
\text { Median }(\mathrm{Q} 1, \mathrm{Q} 3)\end{array}$ & $\begin{array}{r}116(62.7 \%) \\
49(26.5 \%) \\
20(10.8 \%) \\
0(0,5)\end{array}$ & $\begin{array}{r}34(23.9 \%) \\
49(34.5 \%) \\
59(41.5 \%) \\
5(5,10)\end{array}$ & $\begin{array}{r}2(11.1 \%) \\
2(11.1 \%) \\
14(77.8 \%) \\
10(8.75,10)\end{array}$ & $\begin{array}{r}152 \\
100 \\
93\end{array}$ & 59.04 & $<0.001$ \\
\hline
\end{tabular}

\begin{tabular}{|c|c|c|c|c|c|c|c|}
\hline \multirow[b]{2}{*}{ Parafunctional Habits } & \multirow[b]{2}{*}{ B } & \multirow[b]{2}{*}{ S.E. } & \multirow[b]{2}{*}{ p } & \multirow[b]{2}{*}{$\operatorname{Exp}(B)$} & \multicolumn{2}{|c|}{ 95\% C.I.for EXP(B) } & \multirow[b]{2}{*}{ VIF $^{*}$} \\
\hline & & & & & Lower & Upper & \\
\hline Clenching & .648 & .400 & .105 & 1.911 & .873 & 4.183 & 1.217 \\
\hline Grinding & 1.231 & .600 & .040 & 3.424 & 1.057 & 11.094 & 1.184 \\
\hline Biting of lips & 1.025 & .253 & .000 & 2.788 & 1.697 & 4.580 & 1.094 \\
\hline Biting of objects & .429 & .268 & .110 & 1.535 & .908 & 2.598 & 1.051 \\
\hline Mouth breathing & .668 & .298 & .025 & 1.951 & 1.088 & 3.497 & 1.039 \\
\hline
\end{tabular}

*Calculated by linear regression procedure.

\section{DISCUSSION}

The study was aimed to evaluate the prevalence of signs and symptoms of TMD and its association with the parafunctional habits in the undergraduate students of KIST Medical College through distribution of questionnaires.

A total of 345 dental and medical undergraduate students were included in this study, out of which $133(38.6 \%)$ were males and $212(61.4 \%)$ were females.

In this study, a total of $47.4 \%$ of students had some degree of TMD, more than half $(53.6 \%)$ did not have TMD. This was in accordance to the results obtained by previous studies reporting that 
the non-TMD was higher than TMD group. ${ }^{8-13}$ In contrast to our findings, few study reported higher amount of TMD group. ${ }^{14,}{ }^{15}$ In our study, mild TMD was most prevalent in both sexes. Mild TMD was observed in $41.2 \%$ and moderate TMD in $5.2 \%$ of participants. Other investigators also observed similar results. ${ }^{1,2,11}$ The difference may be due to the racial variation, age groups and sample size. In our study the severe TMD group was not found. Almost similar findings was also reported by Agarwal et al. ${ }^{8}$ which evaluated 407 students. However, the age group of students was $15-17$ years.

In this study higher frequency of signs and symptoms of TMD was observed in females. Other investigators likewise observed similar finding. ${ }^{7,11,12,16}$ Hormonal, genetic and emotional factors have been suggested for the higher prevalence of TMD among females. Higher percentage of females in contrast to males in our study may be due to higher number of females enrolling in the undergraduate dental programme.

The most common habit in our study was chewing gums, followed by biting of lips and objects. Similar nail biting and mouth breathing were also present. Statistically significant association was found with clenching, grinding, biting of lips and objects and mouth breathing. These results were in accordance to other studies. ${ }^{7,8,17}$ However, Emodi-Perlman A et al. ${ }^{6}$ found no association. The parafunctional habits should be considered as a risk factor for TMD as they have a deleterious effect on the stomatognathic system.

A patient with TMD usually experience pain in the joint followed by sound in joint and difficulty in opening mouth. ${ }^{17}$ Studies done by Motta et al. ${ }^{17}$ and Bonjardim et al. ${ }^{18}$ have shown similar findings with joint pain followed by joint sounds and difficulty in opening mouth. In contrast to these findings, the present study show feeling of a tense person to the most frequent sign $(56 \%)$ followed by headache, muscular pain while chewing and sounds in the joint.
The present study was aimed to identify the association between the parafunctional habits and sign and symptoms of TMD among the undergraduate students of KIST Medical College and Teaching Hospital. There was statistically significant association between parafunctional habits (clenching, grinding, biting of lips, biting of objects and mouth breathing) and TMD which was in line with the study done by Moteghare et al. ${ }^{7}$ Bivariate analysis revealed the significant association of chewing gums, biting of lips, biting of objects, nail biting and mouth breathing with TMD. However multivariate analysis confirmed the significant relation of biting of lips, grinding of teeth and mouth breathing with TMD where as others parameters did not show significant impact.

The study also has limitations. Although this was a cross sectional study design, odds ratio was calculated to observe the association between parafunctional habits and TMD. The sampling method also does not allow generalizing this study to other population.

\section{CONCLUSIONS}

According to the results obtained we concluded that the prevalence of TMD in KIST Medical College students was similar to that reported in literatures. Mild and moderate types of TMD were present, with females showing greater prevalence than males. A statistically significant association was found between biting of lips, grinding of teeth and mouth breathing and TMD. The present study was a cross-sectional study. The authors would further like to recommend a longitudinal study.

\section{ACKNOWLEDGEMENT}

The authors would like to acknowledge all the students who participated in this study.

\section{REFERENCES}

1. de Oliveira AS, Dias EM, Contato RG, Berzin F. Prevalence study of signs and symptoms of temporomandibular disorder in Brazilian college students. Brazilian oral research. 2006;20(1):37.http://dx.doi.org/10.1590/S180683242006000100002.

2. Nomura K, Vitti M, Oliveira AS, Chaves TC, Semprini M, Siessere S, et al. Use of the Fonseca's questionnaire to assess the prevalence and severity of temporomandibular disorders in Brazilian dental undergraduates. Brazilian dental journal. 2007;18(2):163-7.http://dx.doi.org/10.1590/ S0103-64402007000200015.

3. Modi P, Shaikh SS, Munde A. A cross sectional study of prevalence of temporomandibular disorders in university students. Int J Sci Res Publ. 2012;2(9):13.http://www.ijsrp.org/research-paper-0912/ ijsrp-p0909.pdf

4. de Santis TO, Motta LJ, Biasotto-Gonzalez DA, Mesquita-Ferrari RA, Fernandes KP, de Godoy $\mathrm{CH}$, et al. Accuracy study of the main screening tools for temporomandibular 
Acharya et al. Temporomandibular Joint Disorders and its Relationship with parafunctional..

disorder in children and adolescents. Journal of bodywork and movement therapies. 2014;18(1):87 -91.https://doi.org/10.1016/j.jbmt.2013.05.018.

5. Helkimo M. Studies on function and dysfunction of the masticatory system. 3. Analyses of anamnestic and clinical recordings of dysfunction with the aid of indices. Sven Tandlak Tidskr. 1974;67(3):165-81.PMID: 4526188.

6. Emodi-Perlman A, Eli I, Friedman-Rubin P, Goldsmith C, Reiter S, Winocur E. Bruxism, oral parafunctions, anamnestic and clinical findings of temporomandibular disorders in children. Journal of oral rehabilitation. 2012;39(2):126-35.https:// doi.org/10.1111/j.1365-2842.2011.02254.x.

7. Motghare V, Kumar J, Kamate S, Kushwaha S, Anand R, Gupta N, et al. Association Between Harmful Oral Habits and Sign and Symptoms of Temporomandibular Joint Disorders Among Adolescents. Journal of clinical and diagnostic research : JCDR. 2015;9(8):ZC45-8.doi: 10.7860/ JCDR/2015/12133.6338.

8. Agarwal K, Saha S, Sinha P. Prevalence of temporomandibular disorders and its association with parafunctional habits among senior-secondary school children of Lucknow, India. Journal of Indian Association of Public Health Dentistry. 2016;14(2):139-43.doi: 10.4103/23195932.183809 .

9. Conti A, Freitas M, Conti P, Henriques J, Janson G. Relationship between signs and symptoms of temporomandibular disorders and orthodontic treatment: a cross-sectional study. The Angle orthodontist. 2003;73(4):411-7.PMID:12940562.

10. Conti PCA, Ferreira PM, Pegoraro LF, Conti JV, Salvador MC. A cross-sectional study of prevalence and etiology of signs and symptoms of temporomandibular disorders in high school and university students. Journal of orofacial pain. 1996;10(3).PMID: 9161230.

11. Bonjardim LR, Lopes-Filho RJ, Amado G, Albuquerque RL, Goncalves SR. Association between symptoms of temporomandibular disorders and gender, morphological occlusion, and psychological factors in a group of university students. Indian Journal of Dental Research. 2009;20(2):190.DOI:10.4103/0970-9290.52901, PMID: 19553721.
12. Shiau YY, Chang C. An epidemiological study of temporomandibular disorders in university students of Taiwan. Community dentistry and oral epidemiology. 1992;20 (1) : 43 - 7. PMID : 1547612 , https :// doi.org/10.1111/j.16000528.1992.tb00672.x.

13. Otuyemi O, Owotade F, Ugboko V, Ndukwe $\mathrm{K}$, Olusile O. Prevalence of signs and symptoms of temporomandibular disorders in young Nigerian adults. Journal of Orthodontics. 2000;27(1):61-6.https:// doi.org/10.1093/ortho/27.1.61.

14. Pedroni C, De Oliveira A, Guaratini M. Prevalence study of signs and symptoms of temporomandibular disorders in university students. Journal of oral rehabilitation. 2003;30(3):283-9.https://doi.org/10.1046/ j.1365-2842.2003.01010.x.

15. Schiffman EL, Fricton JR, Haley DP, Shapiro BL. The prevalence and treatment needs of subjects with temporomandibular disorders. The Journal of the American Dental Association. 1990;120(3):295-303.https:// doi.org/10.14219/jada.archive.1990.0059.

16. Rani S, Pawah S, Gola S, Bakshi M. Analysis of Helkimo index for temporomandibular disorder diagnosis in the dental students of Faridabad city: A cross-sectional study. The Journal of Indian Prosthodontic Society. 2017; 17(1):48 -52.DOI: $10.4103 / 0972$ 4052.194941, PMID:28216845.

17. Motta LJ, Guedes CC, De Santis TO, Fernandes S, Porta K, Mesquita-Ferrari RA, et al. Association between parafunctional habits and signs and symptoms of temporomandibular dysfunction among adolescents. Oral health \& preventive dentistry. 2013;11(1). PMID:23507675, DOI:10.3290/j.ohpd.a29369.

18. Bonjardim LR, Gavião MBD, Pereira LJ, Castelo PM, Garcia RCMR. Signs and symptoms of temporomandibular disorders in adolescents. Brazilian oral research. 2005;19 (2):93-8.http://dx.doi.org/10.1590/S180683242005000200004 .

Citation: Acharya S, Chaulagain R, Pradhan A, Shah A. Temporomandibular Joint Disorders and its Relationship with Parafunctional Habits among Undergraduate Medical and Dental Students. JCMS Nepal. 2018;14(3):154-9. 